\title{
Comparison of Quality and Nutritional Components of Eggs from Blue Peafowl and Hen
}

\author{
Yang Fu-min ${ }^{1, *}$, Xu Xiao-xia ${ }^{1,2}$, Yang Min ${ }^{3}$, Qiang Kai-xia ${ }^{4}$, Wang Xue-yan ${ }^{1}$ \\ ${ }^{1}$ College of Food Science and Engineering, Gansu Agricultural University, Lanzhou, China \\ ${ }^{2}$ Gansu Agriculture Technology College, Lanzhou, China \\ ${ }^{3}$ College of Science, Gansu Agricultural University, Lanzhou, China \\ ${ }^{4}$ Qingshui Center for Disease Control and Prevention, Qingshui, China \\ Corresponding author: yfumin@163.com
}

Received March 21, 2014; Revised April 18, 2014; Accepted April 25, 2014

\begin{abstract}
The study was undertaken to compare the quality and nutritional components of eggs from blue peafowl and Jingbai hen. The results showed that the average egg weight, eggshell thickness and egg yolk relative weight of blue peafowl eggs were significantly bigger than those of hen eggs $(p<0.01)$. Blue peafowl eggs contained significantly higher protein $(p<0.01)$, higher carbohydrate $(p<0.01)$, total amino acid and essential amino acid $(p<$ $0.01)$, Zn $(p<0.01)$, Ca $(p<0.05)$ but lower fat $(p<0.01)$ and water $(p<0.05)$ than those in hen eggs. Amino acid content of blue peafowl eggs was in accordance with the ideals of the FAO mode. Blue peafowl eggs contained significantly higher $\mathrm{V}_{\mathrm{C}}$ and $\mathrm{V}_{\mathrm{B} 2}(p<0.01)$ but lower $\mathrm{V}_{\mathrm{A}}$ and $\mathrm{V}_{\mathrm{E}}(p<0.01)$ than hen eggs. 47 volatile compounds were found in raw blue peafowl eggs while only 30 in raw hen eggs; 60 volatile compounds were found in cooked blue peafowl eggs while only 41 in cooked hen eggs. Overall, most indices of qualities and nutrient components of blue peafowl eggs were not inferior to hen eggs.
\end{abstract}

Keywords: blue peafowl egg, hen egg, composition, nutritional quality

Cite This Article: Yang Fu-min, Xu Xiao-xia, Yang Min, Qiang Kai-xia, and Wang Xue-yan, "Comparison of Quality and Nutritional Components of Eggs from Blue Peafowl and Hen." Journal of Food and Nutrition Research, vol. 2, no. 4 (2014): 141-147. doi: 10.12691/jfnr-2-4-2.

\section{Introduction}

Blue peafowl (Pavo cristatus), known as phoenix. In most countries, blue peafowl is a kind of special poultry for viewing and admiring. Now they are raised in most of countries. Wild green peafowl is listed as the national first-class protected animals in China, while home-raised blue peafowl is not included, so they can be raised for food. The blue peafowl can averagely produce 30 eggs a year, and each egg is $90-120$ grams.

Eggs are widely used as ingredient in food industry because of their nutritional, functional and good sensory qualities. Egg quality includes outside quality and inside quality. Outside quality contains egg weight, egg shape index, egg shell thickness, ratio of protein and ratio of egg yolk, etc. Inside quality is always evaluated with Haugh unit, protein height, egg $\mathrm{pH}$, and egg specific gravity, etc. Egg nutrition includes crude protein, fat, cholesterol, moisture, and so on. Since each kind of bird has different genetic background, their egg qualities and nutrition components are variable. Generally, egg shape index, eggshell weight, yolk color and ratio in local hens were better than those in commercial chicks [1]. Egg quality of Hy-line brown was better than that of Jingbai hen, but nutrient content of Hy-line brown was lower than hen [2]. The protein, phosphatide and amino acid of hen eggs are lower than those of dark eggs and quail eggs [3]. As a matter of fact, egg qualities and nutrition components from same species may vary significantly as a result of differences in breed, feed, feeding way, growing environment [4-9].

Blue peafowl eggs can be used for food, but its quality and nutrient components has not been reported. The aim of this research was therefore to evaluate the quality and nutrient components of blue peafowl eggs. Jingbai eggs, widely consumed in most Chinese dishes, were taken as control for comparison. The results could provide reference for people to choose reasonable nutrition, and also offer theoretical basis for the food processing and utilization of blue peafowl genetic resources.

\section{Materials and Methods}

\subsection{Blue Peafowl Eggs and Jingbai Hen Eggs}

Total of 100 fresh eggs were produced by blue peafowls aged at four years, randomly collected less than $24 \mathrm{~h}$ after laying (Gansu Hongxiang blue peafowl hightech agricultural development Co. Ltd). Total of 100 fresh Jingbai hen eggs were randomly obtained from local chicken farm. Egg samples were stored for $24 \mathrm{~h}$ at room temperature before measurements were performed. 


\subsection{Egg Quality Analysis}

Each egg was initially weighed using an Egg Analyzer (ORKA Food Technology Ltd., Ramat Hasharon, Israel). Length and width diameters of eggs were measured using vernier caliper, and egg shape index were calculated according to formula (egg shaped index = length diameter / width diameter). Eggshell thickness was a mean of measurements taken at three locations on the egg (air cell, equator, and sharpend) with an EggShell Thickness Gauge (ESTG-1, ORKA Food Technology Ltd., Ramat Hasharon, Israel). The saturated solution floating method was used to test egg specific gravity. That is, the concentrations of saline were gradually increased from $1.068-1.100 \mathrm{~g} \cdot \mathrm{mL}^{-1}$ by a gradient of $0.004 \mathrm{~g} \cdot \mathrm{mL}^{-1}$. The minimal saline concentration in which eggs can be freely floated on was regarded as egg specific gravity. Then, the egg was broken, and the egg's contents (albumin and yolk) were placed on the measuring tray of the Egg Analyzer for the automatic determination of egg yolk height and albumen height [10]. The Haugh unit was calculated as $100 \log \left(\mathrm{H}+1.7 \mathrm{~W}^{0.37}+\right.$ 7.6), where $\mathrm{H}$ is the albumen height ( $\mathrm{mm})$ and $\mathrm{W}$ is the weight of the egg (g). After Haugh gauge unit measurement finished, both egg yolk and album were together transferred into a glass beaker and homogenized for $\mathrm{pH}$ measurement, and whole egg $\mathrm{pH}$ was measured by precision pH-meter (MP512-03, Shanghai Shenke Instrument Co., Ltd.).

\subsection{Nutrient Contents Analysis}

Egg nutrients include general nutrient, mineral elements, amino acid, vitamin and volatile compounds. General nutrient tested included moisture, crude protein, crude fat and cholesterol. Mineral elements were $\mathrm{Ca}, \mathrm{Zn}, \mathrm{Fe}, \mathrm{Mn}$, $\mathrm{Cu}, \mathrm{P}, \mathrm{K}$ and $\mathrm{Na}$. Vitamin included Vitamin $\mathrm{A}$ (abbreviated as $\left.\mathrm{V}_{\mathrm{A}}\right)$, Vitamin $\mathrm{B}_{1}\left(\mathrm{~V}_{\mathrm{B} 1}\right)$, Vitamin $\mathrm{B}_{2}\left(\mathrm{~V}_{\mathrm{B} 2}\right)$, Vitamin $C\left(V_{C}\right)$ and Vitamin $E\left(V_{E}\right)$. Eighteen kinds of amino acids were found in blue peafowl eggs. They all were analyzed according to National Food Safety Standards of P.R. China (abbreviated as GB/T). For example, the moisture was determined according to GB/T 5009.3-2003.

Generally, nutrition value was evaluated by essential amino acid requirement model that the United Nations Food and Agriculture Organization (FAO) recommended in 1981, which was calculated with the formula as below:

$$
\begin{aligned}
\text { Amino acid score }= & \begin{array}{l}
\text { Amino acid content of per } \\
\text { gram protein to be tested }(t e) \\
\text { ideal mode or refer protein }(\mathrm{ro})
\end{array} \times 100
\end{aligned}
$$

\subsection{Volatile Compounds Analysis}

Analyses were performed using a gas chromatography (model 6890, Hewlett-Packard Company, Palo Alto, USA), which was fitted with a splitless injector and Agilent 5973 mass spectrometer (MS) detector (Agilent Technologies, Santa Clara, USA). The components were separated on a SPB-5 capillary column $60 \mathrm{~m} \times 0.32 \mathrm{~mm} \times$ 1.0- $\mu \mathrm{m}$-film thickness, (Supelco, Bellefonte, PA).Helium was used as the carrier gas with a flow rate of $20 \mathrm{~mL} / \mathrm{min}$. The injector temperature was $250^{\circ} \mathrm{C}$. The temperature was programmed at $50^{\circ} \mathrm{C}$ for $2 \mathrm{~min}$, raised from $50^{\circ} \mathrm{C}$ to $270^{\circ} \mathrm{C}$ by a rate of $3^{\circ} \mathrm{C} / \mathrm{min}$, and held constant at $270^{\circ} \mathrm{C}$ for $10 \mathrm{~min}$. Detection was carried out by MS on the total ion current obtained by electron impact at $70 \mathrm{eV}$. Ion source temperature was $200^{\circ} \mathrm{C}$. Scan range was from 30 to $500 \mathrm{amu}$.

Compounds were identified with NIST 98 data bank (NIST/EPA/NISH Mass Spectral Library, version 1.6, U.S.A.), using a match factor higher than $97 \%$ and also by comparison of their GC Kovats index and in some cases by comparison of their retention times with those of standard compounds.

The relative content of volatile flavor compounds was quantitatively determined by peak area normalization method.

\subsection{Statistical Analysis}

All the measurements were carried out in triplicate; the values were averaged and reported along with their standard deviation (S.D). Data were analyzed with paired $t$ test. Probabilities lower than 0.01 were considered as statistically highly significant $(p<0.01)$. Probabilities lower than 0.05 were considered as statistically significant $(p<0.05)$. All statistical calculations were performed with the SPSS 13.0 statistical software for Windows.

\section{Results and Discussion}

\subsection{Egg Quality Characteristics}

Quality indexes of blue peafowl and hen eggs are shown in Table 1. Egg weight, egg yolk index, egg protein relative weight, egg yolk relative weight and eggshell thickness were significantly different $(p<0.01)$ between two species eggs, while egg shape index, eggshell relative weight, ratio of egg yolk and egg protein, Haugh unit, whole egg $\mathrm{pH}$ and egg specific gravity were not

\begin{tabular}{|c|c|c|c|}
\hline Indexes & Blue peafowl & Jingbai hen & $\begin{array}{c}p- \\
\text { value }\end{array}$ \\
\hline Egg weight (g) & $94.400 \pm 4.681$ & $48.531 \pm 3.183$ & $* *$ \\
\hline Egg shape index & $1.337 \pm 0.046$ & $1.322 \pm 0.051$ & NS \\
\hline Egg yolk index & $0.445 \pm 0.151$ & $0.693 \pm 0.123^{\text {B }}$ & $* *$ \\
\hline $\begin{array}{l}\text { Egg protein relative } \\
\text { weight (\%) }\end{array}$ & $43.409 \pm 2.617$ & $60.041 \pm 2.260^{\mathrm{B}}$ & $* *$ \\
\hline $\begin{array}{l}\text { Egg yolk relative } \\
\text { weight (\%) }\end{array}$ & $42.993 \pm 2.815$ & $28.752 \pm 1.883$ & $* *$ \\
\hline $\begin{array}{l}\text { Eggshell relative } \\
\text { weight (\%) }\end{array}$ & $13.598 \pm 0.712$ & $12.294 \pm 0.432$ & NS \\
\hline $\begin{array}{l}\text { Ratio of egg yolk } \\
\text { and protein (\%) }\end{array}$ & $99.879 \pm 12.141$ & $87.466 \pm 9.786$ & NS \\
\hline Haugh unit $(\mathrm{Hu})$ & $74.033 \pm 2.534$ & $72.601 \pm 6.420$ & NS \\
\hline Whole egg pH & $7.120 \pm 1.852$ & $7.062 \pm 0.887$ & NS \\
\hline $\begin{array}{l}\text { Egg specific gravity } \\
\qquad\left(\mathrm{g} / \mathrm{cm}^{3}\right)\end{array}$ & $1.095 \pm 0.043$ & $1.087 \pm 0.005$ & NS \\
\hline $\begin{array}{c}\text { Eggshell thickness } \\
(\mathrm{mm})\end{array}$ & $0.488 \pm 0.004$ & $0.363 \pm 0.041$ & $* *$ \\
\hline
\end{tabular}
significantly different $(p>0.05)$.

Table 1. Quality indexes of blue peafowl and hen eggs ( $\bar{X} \pm S, \mathbf{n}=3$ )

Egg weight is largely determined by genetic factors, as well as poultry weight, age at first egg, temperature and feed nutrition [11]. Blue peafowl average egg weight is

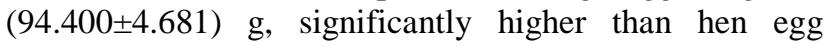


$(48.531 \pm 3.183) \mathrm{g}$. The main reason of this difference is due to the genetic factors.

Egg shape index influenced hatchability [12,13], which is one of the indicators for classifying avian species. A particular kind of avian species tend to have certain eggshaped index. Normal egg index is generally about 1.29 1.39 [14]. The blue peafowl egg index was $1.34 \pm 0.046$, being considered in the normal range.

Egg specific gravity could reflect the freshness of egg, and it also associated with shell thickness [15]. Normal egg specific gravity is in the range $1.06 \sim 1.10 \mathrm{~g} / \mathrm{cm}^{3}$, and the egg specific gravity of good quality egg is bigger than $1.08 \mathrm{~g} / \mathrm{cm}^{3}$. The blue peafowl eggs specific gravity was $(1.095 \pm 0.043) \mathrm{g} / \mathrm{cm}^{3}$, denoting its quality was better than that of hen eggs. Blue peafowl eggshell thickness was thicker than that of hen eggs ( $p<0.01)$, which was more advantageous in transportation and storage.

Ratio of egg yolk and whole egg has great influence on nutrients content of egg. Egg yolk nutrients are more complex than egg protein, which has more rich nutrition [16]. In this study, blue peafowl egg yolk accounted for $42.99 \%$ of whole egg, $14.24 \%$ higher than that of hen egg; the ratio of egg yolk and protein reached up to $99.88 \%$, $12.41 \%$ higher than hen eggs, these results indicated blue peafowl egg nutritional value was higher than hen egg.

Haugh unit is one of the egg quality category standard set by United States Department of Agriculture [10], Haugh unit is greater than 72 to AA grade, greater than 55 or less than 71 to A grade, less than 60 to $\mathrm{B}$ grade. Grade AA and A eggs are edible eggs, while B level is not suitable to eat. The Haugh unit of blue peafowl egg was 74.033 \pm 2.534 , which showed that blue peafowl egg protein quality was good than that of hen egg.

\subsection{General Nutrient}

Table 2. Nutrient contents in blue peafowl and hen eggs (g/100g, $\bar{X} \pm S, \mathbf{n}=3$ )

\begin{tabular}{cccc}
\hline Samples & Blue peafowl & Jingbai hen & $p$-value \\
\hline Moisture & $65.231 \pm 3.433$ & $73.202 \pm 2.885$ & $*$ \\
Protein & $15.554 \pm 0.076$ & $12.602 \pm 1.007$ & $* *$ \\
Fat & $0.923 \pm 0.002$ & $10.501 \pm 0.879$ & $* *$ \\
Cholesterol & $0.543 \pm 0.013$ & $0.585 \pm 0.206$ & $N S$ \\
\hline Carbohydrate & $16.982 \pm 0.044$ & $1.501 \pm 0.018$ & $* *$ \\
\hline & ${ }^{* *} p<0.01 ; * p<0.05 ;$ NS $p \geq 0.05$. & \\
\hline
\end{tabular}

Moisture, protein, fat, carbohydrate and cholesterol contents are shown in Table 2. The mean moistrure content of blue peafowl eggs was lower than that of hen eggs $(p<0.05)$, and lower to the value reported for duck $(70.82 \%)$ [8,17], quail (70.60\%) [3] and ostrich (75.1\%) [18]. The protein, fat and carbohydrate content of two kinds of eggs differed significantly ( $p<0.01$ ), while the cholesterol content was found no significant $(p>0.05)$. The fat content of blue peafowl eggs was only $(0.923 \pm 0.002) \mathrm{g} / 100 \mathrm{~g}$, far lower than that of hen eggs $(10.501 \pm 0.879) \mathrm{g} / 100 \mathrm{~g}$, and lower than those of duck (10.5 12.21\%) [8,17] (Zhou and others 2009; Wei and others 2012), quail (8.22\%) [3] (Chen and others 2005) and ostrich (11.7\%) [18]. The protein content of blue peafowl eggs was $(15.554 \pm 0.076) \mathrm{g} / 100 \mathrm{~g}$, higher than that of hen eggs $(12.602 \pm 1.007) \mathrm{g} / 100 \mathrm{~g}$, and those of duck (13.1\%) [8,17], quail (14.73\%) [3] and ostrich (12.2\%) [18]. The carbohydrate content of blue peafowl eggs was higher than that of hen eggs. The cholesterol content of blue peafowl egg appeared similar to the value for hen egg $(0.585 \pm 0.206) \mathrm{g} / 100 \mathrm{~g}$ but much lower compared to the value reported for black hen $(0.612 \%)$ and quail $(0.866 \%)$ [3].

The nutrient differences between two kinds of eggs, especially for protein $\backslash$ fat and carbohydrate, may be caused by genetic background, feed, growing environment, etc. As a whole, blue peafowl egg was considered to be a kind of food with high protein, high carbohydrate and low fat compared to hen and other avian eggs.

\subsection{Mineral}

Table 3 presents the mineral element content of two kinds of eggs. Except for $\mathrm{Na}$ and Se, the content of $\mathrm{P}, \mathrm{K}$, $\mathrm{Zn}, \mathrm{Mn}, \mathrm{Fe}$ and $\mathrm{Cu}$ in the tested eggs differed significantly $(p<0.01)$. The blue peafowl eggs were found to contain a significantly $(p<0.05)$ higher $\mathrm{Ca}$ content but lower Fe content $(p<0.01)$ than those in hen eggs. It was observed that the blue peafowl eggs presented the highest $(p<0.01)$ $\mathrm{Zn}$ content but the lowest $\mathrm{Cu}$ content $(p<0.01)$ than that of hen eggs. The $\mathrm{Zn}$ content of blue peafowl eggs was 7 times than that of hen eggs, which indicated that blue peafowl eggs may be good food for people who lack of $\mathrm{Zn}$ in daily food.

Table 3. Mineral elements contents in blue peafowl and hen eggs (g/100g, $\bar{x} \pm s, \mathbf{n}=\mathbf{3})$

\begin{tabular}{cccc}
\hline Mineral & Blue peafowl & Jingbai hen & $p$-value \\
\hline $\mathrm{Ca}$ & $0.075 \pm 0.023$ & $0.035 \pm 0.003$ & $*$ \\
$\mathrm{P}$ & $0.032 \pm 0.014$ & $0.162 \pm 0.021$ & $* *$ \\
$\mathrm{~K}$ & $0.055 \pm 0.033$ & $0.142 \pm 0.034$ & $* *$ \\
$\mathrm{Na}$ & $0.198 \pm 0.107$ & $0.058 \pm 0.025$ & $N S$ \\
$\mathrm{Zn}$ & $19.690 \pm 0.043$ & $2.880 \pm 0.032$ & $* *$ \\
$\mathrm{Se}$ & $0.060 \pm 0.061$ & $0.017 \pm 0.003$ & $N S$ \\
$\mathrm{Mn}$ & $1.340 \pm 0.012$ & $0.010 \pm 0.003$ & $* *$ \\
$\mathrm{Fe}$ & $2.020 \pm 0.007$ & $4.520 \pm 0.022$ & $* *$ \\
$\mathrm{Cu}$ & $0.003 \pm 0.001$ & $0.130 \pm 0.020$ & $* *$ \\
\hline \multicolumn{4}{c}{}
\end{tabular}

\subsection{Amino Acid}

\begin{tabular}{|c|c|c|c|}
\hline Amino acids & Blue peafowl & Jingbai hen & $p$-value \\
\hline Thr $^{*}$ & $0.63 \pm 0.026$ & $0.61 \pm 0.007$ & $N S$ \\
\hline $\mathrm{Val}^{*}$ & $0.82 \pm 0.048$ & $0.69 \pm 0.009$ & $* *$ \\
\hline Met $^{*}$ & $0.51 \pm 0.017$ & $0.48 \pm 0.027$ & NS \\
\hline Ile $^{*}$ & $0.68 \pm 0.029$ & $0.55 \pm 0.033$ & $* *$ \\
\hline $\mathrm{Leu}^{*}$ & $1.09 \pm 0.021$ & $1.03 \pm 0.008$ & $* *$ \\
\hline $\mathrm{Phe}^{*}$ & $0.69 \pm 0.054$ & $0.63 \pm 0.033$ & NS \\
\hline Lys* & $0.95 \pm 0.018$ & $0.82 \pm 0.025$ & $* *$ \\
\hline Trp & $0.15 \pm 0.003$ & $0.16 \pm 0.01$ & NS \\
\hline Asp $^{\#}$ & $1.27 \pm 0.025$ & $1.26 \pm 0.027$ & NS \\
\hline Ser & $0.96 \pm 0.012$ & $0.96 \pm 0.072$ & NS \\
\hline Glu $^{\#}$ & $1.7 \pm 0.054$ & $1.76 \pm 0.071$ & NS \\
\hline Gly $^{\#}$ & $0.41 \pm 0.009$ & $0.42 \pm 0.027$ & NS \\
\hline $\mathrm{Ala}^{\#}$ & $0.79 \pm 0.012$ & $0.7 \pm 0.018$ & $* *$ \\
\hline Tyr & $0.58 \pm 0.015$ & $0.47 \pm 0.030$ & $* *$ \\
\hline His & $0.31 \pm 0.016$ & $0.28 \pm 0.035$ & NS \\
\hline $\operatorname{Arg}^{\#}$ & $0.77 \pm 0.034$ & $0.77 \pm 0.026$ & NS \\
\hline Pro & $0.41 \pm 0.010$ & $0.37 \pm 0.031$ & NS \\
\hline Cys & $0.32 \pm 0.022$ & $0.27 \pm 0.014$ & $*$ \\
\hline TAA & 13.04 & 12.23 & $* *$ \\
\hline EAA & 5.52 & 4.97 & $* *$ \\
\hline EAA/TAA (\%) & 42.33 & 40.64 & \\
\hline EAA/NEAA (\%) & 73.40 & 68.46 & \\
\hline FAA & 4.94 & 4.91 & \\
\hline FAA/TAA (\%) & 37.88 & 40.15 & \\
\hline \multicolumn{4}{|c|}{$\begin{array}{c}* * p<0.01 ; * p<0.05 ; \text { NS } p \geq 0.05 \text {. TAA=Total amino acids; } \\
* \text { EAA=Essential amino acids; NEAA=Nonessential amino acids; } \\
\text { \#FAA=Flavor amino acids. }\end{array}$} \\
\hline
\end{tabular}


As shown in Table 4, there were 18 kinds of amino acids in blue peafowl eggs and hen eggs. Both of examined eggs were found to contain the highest Glu content $(1.7 \pm 0.054$ and $1.76 \pm 0.071 \mathrm{~g} / 100 \mathrm{~g}$, respectively). Greater Val, Ile, Leu, Lys, Ala and Tyr content $(p<0.01)$ were noticeable in the blue peafowl eggs compared to those in hen eggs. The Cys content of the blue peafowl eggs was twice times than that of hen eggs $(p<0.05)$. It was observed that the total amino acid (TAA) and essential acid (EAA) content in blue peafowl eggs reached $13.04 \mathrm{~g} / 100 \mathrm{~g}$ and $5.52 \mathrm{~g} / 100 \mathrm{~g}$ respectively, higher than those in hen eggs $(p<0.01)$. There was no significant difference in the content of flavor amino acids (FAA) including Asp, Glu, Arg, Ala and Gly between two kinds of eggs $(p>0.05)$.

\subsection{Amino Acid Nutrition Value}

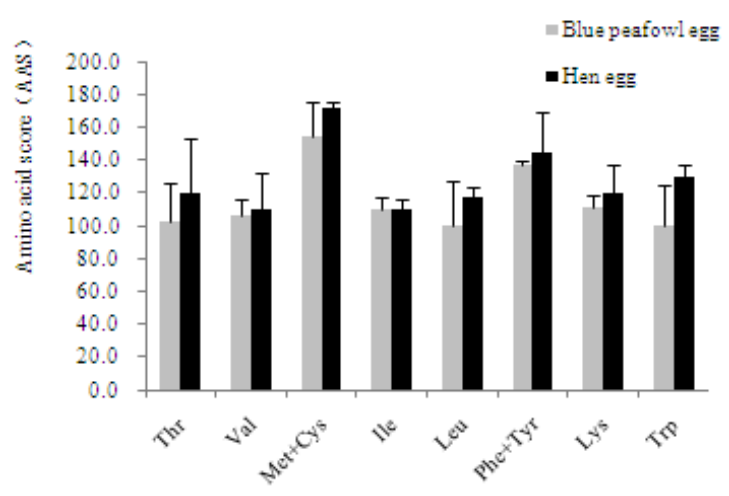

Figure 1. Comparison of essential amino acids in blue peafowl and hen eggs with $\mathrm{FAO} / \mathrm{WHO}$ standard (mg/gN)
The FAO ideal mode is defined as amino acid supply of human body by the United Nations Food and Agriculture Organization (FAO) according to the amino acid structure proportion of eggs and milk. Figure 1 showed the essential amino acid scores (AAS) of blue peafowl eggs and hen eggs compared with the amino standard model set by the FAO.

The AAS of Ile was found to be similar in two kinds of eggs, while the AAS of other amino acids in blue peafowl eggs were lower than that of hen eggs. The AAS of Thr, Val, Leu and Lys in blue peafowl eggs were all closer to the ideal model. Among the AAS determined, Met+Cys were the highest in both two kinds of eggs.

\subsection{Vitamin}

Table 5 showed the contents of $\mathrm{V}_{\mathrm{B} 1}, \mathrm{~V}_{\mathrm{B} 2}, \mathrm{~V}_{\mathrm{C}}, \mathrm{V}_{\mathrm{A}}$ and $\mathrm{V}_{\mathrm{E}}$ in two kinds of eggs. The $\mathrm{V}_{\mathrm{B} 1}, \mathrm{~V}_{\mathrm{C}}, \mathrm{V}_{\mathrm{A}}$ and $\mathrm{V}_{\mathrm{E}}$ content of two kinds of eggs differed significantly $(p<0.01)$. The content of $\mathrm{Vc}$ in Jingbai eggs was not detect out, and it may attribute to low content.

Table 5. Vitamin contents in blue peafowl and hen eggs $(\mathrm{mg} / 100 \mathrm{~g}$, $\bar{X} \pm s, \mathbf{n}=3$ )

\begin{tabular}{cccc}
\hline Samples & Blue peafowl & Jingbai hen & $p$-value \\
\hline $\mathrm{V}_{\mathrm{B} 1}$ & $0.130 \pm 0.033$ & $0.110 \pm 0.045$ & $* *$ \\
$\mathrm{~V}_{\mathrm{B} 2}$ & $0.410 \pm 0.003$ & $0.270 \pm 0.006$ & $N S$ \\
$\mathrm{~V}_{\mathrm{C}}$ & $30.300 \pm 2.045$ & - & $* *$ \\
$\mathrm{~V}_{\mathrm{A}}$ & $0.030 \pm 0.016$ & $0.230 \pm 0.022$ & $* *$ \\
$\mathrm{~V}_{\mathrm{E}}$ & $0.020 \pm 0.007$ & $1.840 \pm 0.053$ & $* *$ \\
\hline \multicolumn{4}{c}{$p<0.01 ; * p<0.05 ;$ NS $p \geq 0.05}$. \\
\end{tabular}

\subsection{Volatile Compounds}

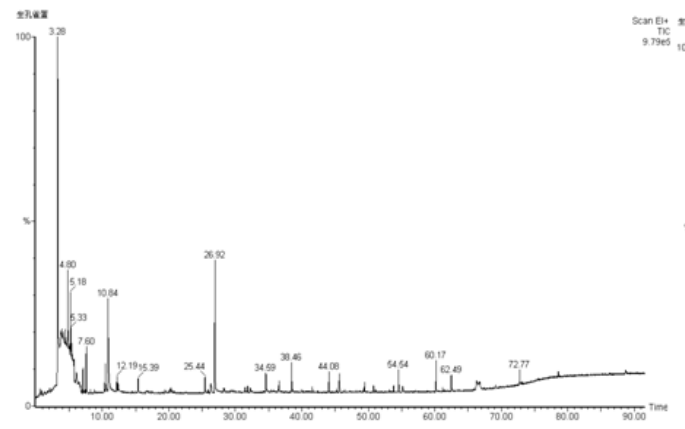

(a) Raw blue peafowl eggs

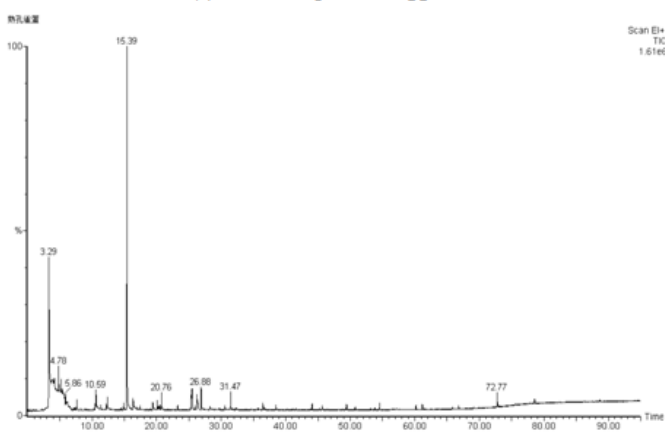

(c) Cooked blue peafowl eggs

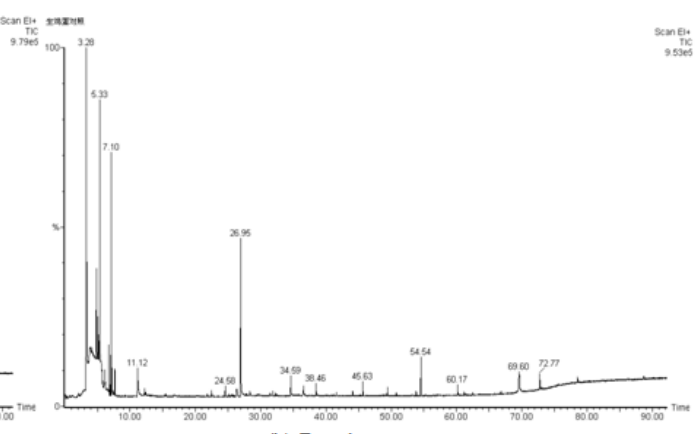

(b) Raw hen eggs

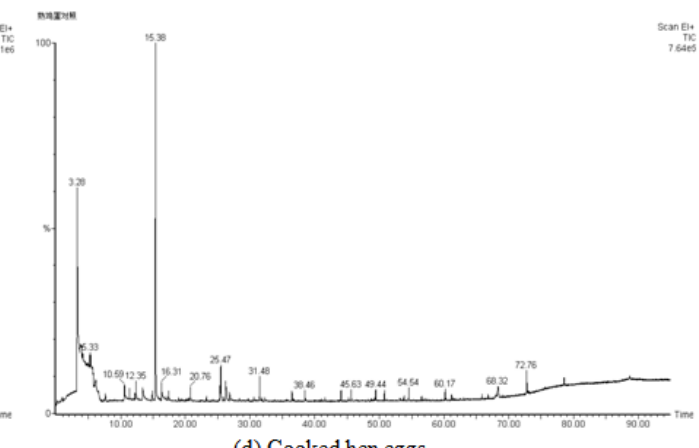

(d) Cooked hen eggs

Figure 2. Total ionic flow chart of volatile compounds in blue peafowl and hen eggs

Each egg has its own characteristic volatile substances which exhibits its special flavor and odor. These compounds characterize not only eggs' quality but also taste. Gas chromatography analysis of the volatile compounds from blue peafowl eggs and hen eggs are shown in Figure 2. The volatile compounds in raw blue peafowl eggs and hen eggs are listed in Table 6. 
Table 6. Volatile compounds in raw blue peafowl and hen eggs

\begin{tabular}{|c|c|c|c|c|c|}
\hline \multirow{2}{*}{$\frac{\text { Number }}{1}$} & \multirow{2}{*}{$\begin{array}{c}\text { Time } \\
4.45\end{array}$} & \multirow{2}{*}{$\begin{array}{l}\text { Volatile Compounds } \\
\text { 1,2-diethoxy-Ethane }\end{array}$} & \multirow{2}{*}{$\frac{\mathrm{MF}}{\mathrm{C}_{6} \mathrm{H}_{14} \mathrm{O}_{2}}$} & \multicolumn{2}{|c|}{ Content (\%) Blue peafowl Hen } \\
\hline & & & & 12.00 & - \\
\hline 2 & 4.84 & 2-methylpentane & $\mathrm{C}_{6} \mathrm{H}_{14}$ & - & 7.63 \\
\hline 3 & 5.33 & Hexane & $\mathrm{C}_{6} \mathrm{H}_{14}$ & 13.76 & 15.15 \\
\hline 4 & 6.71 & 2-methylhexane & $\mathrm{C}_{7} \mathrm{H}_{16}$ & - & 2.55 \\
\hline 5 & 7.60 & Chloroform & $\mathrm{CHCl}_{3}$ & 1.54 & - \\
\hline 6 & 8.81 & 1,2-dichloro-Ethane & $\mathrm{C}_{2} \mathrm{H}_{4} \mathrm{Cl}_{2}$ & 0.13 & - \\
\hline 7 & 10.46 & Dimethoxymethane & $\mathrm{C}_{3} \mathrm{H}_{8} \mathrm{O}_{2}$ & 1.24 & - \\
\hline 8 & 45.26 & Hendecane & $\mathrm{C}_{11} \mathrm{H}_{24}$ & - & 0.11 \\
\hline 9 & 49.32 & Pentadecane & $\mathrm{C}_{15} \mathrm{H}_{32}$ & 0.11 & 0.24 \\
\hline 10 & 51.09 & 1-chloro-Tetradecane & $\mathrm{C}_{14} \mathrm{H}_{29} \mathrm{Cl}$ & 0.14 & - \\
\hline 11 & 56.84 & n-Hexadecane & $\mathrm{C}_{16} \mathrm{H}_{34}$ & 0.03 & 0.14 \\
\hline 12 & 60.18 & Cyclooctane & $\mathrm{C}_{8} \mathrm{H}_{16}$ & 1.31 & - \\
\hline 13 & 72.76 & Eicosane & $\mathrm{C}_{20} \mathrm{H}_{42}$ & 1.05 & 2.03 \\
\hline 14 & 5.09 & 4-Methyl-1-hexene & $\mathrm{C}_{7} \mathrm{H}_{14}$ & - & 2.14 \\
\hline 15 & 6.12 & 2-methyl-1-pentene & $\mathrm{C}_{6} \mathrm{H}_{12}$ & - & 2.37 \\
\hline 16 & 12.36 & Cycloheptatrien & $\mathrm{C}_{7} \mathrm{H}_{8}$ & 0.37 & - \\
\hline 17 & 19.41 & Cinnamene & $\mathrm{C}_{8} \mathrm{H}_{8}$ & 0.15 & - \\
\hline 18 & 39.90 & Myrcene & $\mathrm{C}_{10} \mathrm{H}_{16}$ & 0.10 & 0.45 \\
\hline 19 & 15.40 & Hexanal & $\mathrm{C}_{6} \mathrm{H}_{12} \mathrm{O}$ & 0.71 & 0.17 \\
\hline 20 & 20.78 & Heptaldehyde & $\mathrm{C}_{7} \mathrm{H}_{14} \mathrm{O}$ & 0.08 & - \\
\hline 21 & 26.34 & Benzaldehyde & $\mathrm{C}_{7} \mathrm{H}_{6} \mathrm{O}$ & 1.17 & 1.76 \\
\hline 22 & 31.48 & Nonenal & $\mathrm{C}_{9} \mathrm{H}_{18} \mathrm{O}$ & 0.29 & 0.35 \\
\hline 23 & 36.48 & Decanal & $\mathrm{C}_{10} \mathrm{H}_{20} \mathrm{O}$ & 0.25 & 0.37 \\
\hline 24 & 40.18 & (z)-3,7-dimethylocta-2,6-dienal & $\mathrm{C}_{10} \mathrm{H}_{16} \mathrm{O}$ & 0.08 & - \\
\hline 25 & 41.19 & Octanal & $\mathrm{C}_{8} \mathrm{H}_{16} \mathrm{O}$ & 0.04 & 0.84 \\
\hline 26 & 41.58 & (E)-3,7-dimethylocta-2,6-dienal & $\mathrm{C}_{10} \mathrm{H}_{16} \mathrm{O}$ & 0.21 & \\
\hline 27 & 45.63 & Dodecanal & $\mathrm{C}_{12} \mathrm{H}_{24} \mathrm{O}$ & 0.92 & - \\
\hline 28 & 53.81 & Undecanal & $\mathrm{C}_{11} \mathrm{H}_{22} \mathrm{O}$ & 0.27 & - \\
\hline 29 & 61.17 & hexadecanal & $\mathrm{C}_{16} \mathrm{H}_{32} \mathrm{O}$ & 0.13 & 0.67 \\
\hline 30 & 5.19 & Acetone & $\mathrm{C}_{3} \mathrm{H}_{6} \mathrm{O}$ & 5.74 & 0.73 \\
\hline 31 & 7.42 & 2-butanone & $\mathrm{C}_{4} \mathrm{H}_{8} \mathrm{O}$ & 0.12 & 0.30 \\
\hline 32 & 20.53 & 2-heptanone & $\mathrm{C}_{7} \mathrm{H}_{14} \mathrm{O}$ & 0.10 & - \\
\hline 33 & 49.43 & 2-Tridecanone & $\mathrm{C}_{13} \mathrm{H}_{26} \mathrm{O}$ & 0.37 & - \\
\hline 34 & 4.81 & Ethyl alcohol & $\mathrm{C}_{2} \mathrm{H}_{6} \mathrm{O}$ & 15.65 & - \\
\hline 35 & 10.27 & 1-Butanol & $\mathrm{C}_{4} \mathrm{H}_{10} \mathrm{O}$ & 0.39 & - \\
\hline 36 & 20.09 & 1-hexanol & $\mathrm{C}_{6} \mathrm{H}_{14} \mathrm{O}$ & 0.12 & - \\
\hline 37 & 25.69 & Cineole & $\mathrm{C}_{10} \mathrm{H}_{18} \mathrm{O}$ & - & 0.21 \\
\hline 38 & 28.24 & 2-Ethyl hexanol & $\mathrm{C}_{8} \mathrm{H}_{18} \mathrm{O}$ & 0.14 & - \\
\hline 39 & 32.26 & Benzyl alchol & $\mathrm{C}_{7} \mathrm{H}_{8} \mathrm{O}$ & 0.32 & 0.45 \\
\hline 40 & 34.20 & 6-amino-2-methyl-2-heptanol & $\mathrm{C}_{8} \mathrm{H}_{19} \mathrm{ON}$ & 0.08 & - \\
\hline 41 & 38.46 & 3,7-dimethyl-6-octen-1-ol & $\mathrm{C}_{10} \mathrm{H}_{20} \mathrm{O}$ & 1.34 & 1.05 \\
\hline 42 & 3.28 & Ethyl L-Alaninate & $\mathrm{C}_{5} \mathrm{H}_{11} \mathrm{O}_{2} \mathrm{~N}$ & 30.06 & 26.06 \\
\hline 43 & 7.12 & exanoic acid ethyl ester & $\mathrm{C}_{4} \mathrm{H}_{8} \mathrm{O}_{2}$ & 0.80 & 13.76 \\
\hline 44 & 46.43 & Butyl isobutyrate & $\mathrm{C}_{8} \mathrm{H}_{16} \mathrm{O}_{2}$ & 0.14 & - \\
\hline 45 & 88.71 & 1,2-Benzenedicarboxylic acid, dioctyl ester & $\mathrm{C}_{24} \mathrm{H}_{38} \mathrm{O}_{4}$ & 0.32 & - \\
\hline 46 & 10.86 & Acetic acid & $\mathrm{C}_{2} \mathrm{H}_{4} \mathrm{O}_{2}$ & 6.78 & 4.60 \\
\hline 47 & 29.34 & Hexanoic acid & $\mathrm{C}_{6} \mathrm{H}_{12} \mathrm{O}_{2}$ & 0.21 & - \\
\hline \multirow[t]{2}{*}{48} & 8.21 & Benzeen & $\mathrm{C}_{6} \mathrm{H}_{6}$ & 0.13 & 0.10 \\
\hline & 12.36 & Toluene & $\mathrm{C}_{7} \mathrm{H}_{8}$ & - & 0.53 \\
\hline 49 & 17.42 & 1,2-Xylene & $\mathrm{C}_{8} \mathrm{H}_{10}$ & 0.09 & 0.30 \\
\hline 50 & 17.01 & Ethyl benzene & $\mathrm{C}_{8} \mathrm{H}_{10}$ & 0.10 & - \\
\hline 51 & 46.19 & 2-methoxy-4-(1-propenyl)-Phen ol & $\mathrm{C}_{10} \mathrm{H}_{12} \mathrm{O}_{2}$ & 0.05 & - \\
\hline 52 & 88.71 & Dimethylbenzene & $\mathrm{C}_{24} \mathrm{H}_{38} \mathrm{O}_{4}$ & - & 0.34 \\
\hline 53 & 5.73 & Tuaminoheptane & $\mathrm{C}_{7} \mathrm{H}_{17} \mathrm{~N}$ & - & 0.64 \\
\hline 54 & 25.44 & Tetrahydro-2,6-dimethoxy-dimethoxy-2H-Pyran & $\mathrm{C}_{7} \mathrm{H}_{14} \mathrm{O}_{3}$ & 0.71 & - \\
\hline 55 & 28.35 & 1,3-Dioxolane & $\mathrm{C}_{3} \mathrm{H}_{6} \mathrm{O}_{2}$ & 0.19 & - \\
\hline 56 & 40.19 & N-(Oxidiethylene)-2-benzothiazolyl sulfenamide & $\mathrm{C}_{7} \mathrm{H}_{5} \mathrm{NS}$ & - & 0.14 \\
\hline
\end{tabular}


Table 7. Volatile compounds in cooked blue peafowl and hen eggs

\begin{tabular}{|c|c|c|c|c|c|}
\hline Number & Time & Volatile Compounds & MF & \multicolumn{2}{|c|}{ Content(\%) Blue peafowl Hen } \\
\hline 1 & 5.33 & Hexane & $\mathrm{C}_{6} \mathrm{H}_{14}$ & - & 1.03 \\
\hline 2 & 7.60 & Chloroform & $\mathrm{CHC}_{13}$ & 0.78 & - \\
\hline 3 & 8.81 & 1,2-dichloro-Ethane & $\mathrm{C}_{2} \mathrm{H}_{4} \mathrm{C}_{2}$ & 0.05 & - \\
\hline 4 & 40.97 & Hen decane & $\mathrm{C}_{11} \mathrm{H}_{24}$ & 0.06 & 0.10 \\
\hline 5 & 11.35 & Octane & $\mathrm{C}_{8} \mathrm{H}_{18}$ & 0.25 & 1.40 \\
\hline 6 & 45.26 & Tridecane & $\mathrm{C}_{13} \mathrm{H}_{28}$ & 0.08 & - \\
\hline 7 & 53.17 & Tetradecane & $\mathrm{C}_{14} \mathrm{H}_{30}$ & 0.08 & 0.58 \\
\hline 8 & 56.83 & Pentadecane & $\mathrm{C}_{15} \mathrm{H}_{32}$ & 0.07 & - \\
\hline 9 & 60.31 & Hexadecane & $\mathrm{C}_{16} \mathrm{H}_{34}$ & 0.06 & - \\
\hline 10 & 72.76 & Eicosane & $\mathrm{C}_{20} \mathrm{H}_{42}$ & 1.25 & 2.13 \\
\hline 11 & 78.56 & Hexatriacontane & $\mathrm{C}_{36} \mathrm{H}_{74}$ & 0.40 & 0.64 \\
\hline 12 & 12.36 & Tropiliden & $\mathrm{C}_{7} \mathrm{H}_{8}$ & 0.95 & - \\
\hline 13 & 19.40 & Cyclooctatetraene & $\mathrm{C}_{8} \mathrm{H}_{8}$ & 0.93 & 0.43 \\
\hline 14 & 24.58 & 1-methyl-4-(1-methylethen yl)-Cyclohexene & $\mathrm{C}_{10} \mathrm{H}_{16}$ & 0.06 & - \\
\hline 15 & 40.19 & Myrcene & $\mathrm{C}_{10} \mathrm{H}_{16}$ & - & 0.08 \\
\hline 16 & 8.90 & 3-methyl-Butanal & $\mathrm{C}_{5} \mathrm{H}_{10} \mathrm{O}$ & 0.07 & - \\
\hline 17 & 10.59 & Pentanal & $\mathrm{C}_{5} \mathrm{H}_{10} \mathrm{O}$ & 3.13 & 2.00 \\
\hline 18 & 15.39 & Hexanal & $\mathrm{C}_{6} \mathrm{H}_{12} \mathrm{O}$ & 25.65 & 24.65 \\
\hline 19 & 16.10 & Octanal & $\mathrm{C}_{8} \mathrm{H}_{16} \mathrm{O}$ & 0.17 & 0.05 \\
\hline 20 & 20.76 & Heptaldehyde & $\mathrm{C}_{7} \mathrm{H}_{14} \mathrm{O}$ & 1.20 & 1.00 \\
\hline 21 & 25.21 & (E)-2-heptenal & $\mathrm{C}_{7} \mathrm{H}_{12} \mathrm{O}$ & 0.22 & - \\
\hline 22 & 26.24 & Benzaldehyde & $\mathrm{C} 7 \mathrm{H} 6 \mathrm{O}$ & 2.44 & 3.50 \\
\hline 23 & 30.58 & (E)-2-octenal & $\mathrm{C}_{8} \mathrm{H}_{14} \mathrm{O}$ & 0.48 & - \\
\hline 24 & 31.48 & Nonenal & $\mathrm{C}_{9} \mathrm{H}_{18} \mathrm{O}$ & 1.29 & 1.64 \\
\hline 25 & 35.69 & (E)-2-nonenal & $\mathrm{C}_{9} \mathrm{H}_{16} \mathrm{O}$ & 0.07 & - \\
\hline 26 & 36.47 & Decanal & $\mathrm{C}_{10} \mathrm{H}_{20} \mathrm{O}$ & 0.51 & 0.74 \\
\hline 27 & 41.58 & (E)-3,7-dimethyl-2,6-octadienaldehyde & $\mathrm{C}_{10} \mathrm{H}_{16} \mathrm{O}$ & 0.17 & 0.31 \\
\hline 28 & 43.88 & (E,E)-2,4-decadienal & $\mathrm{C}_{10} \mathrm{H}_{16} \mathrm{O}$ & 0.06 & - \\
\hline 29 & 45.64 & Undecanal & $\mathrm{C}_{11} \mathrm{H}_{22} \mathrm{O}$ & 0.42 & 1.39 \\
\hline 30 & 53.81 & Dodecanal & $\mathrm{C}_{12} \mathrm{H}_{24} \mathrm{O}$ & 0.17 & - \\
\hline 31 & 57.59 & Tedradecane & $\mathrm{C}_{14} \mathrm{H}_{28} \mathrm{O}$ & 0.04 & - \\
\hline 32 & 61.17 & Hexadecanal & $\mathrm{C}_{16} \mathrm{H}_{32} \mathrm{O}$ & 0.36 & - \\
\hline 33 & 61.43 & 1,4-phthalic aldehyde & $\mathrm{C}_{8} \mathrm{H}_{6} \mathrm{O} 2$ & 0.10 & - \\
\hline 34 & 5.18 & Propanone & $\mathrm{C}_{3} \mathrm{H}_{6} \mathrm{O}$ & 13.41 & 0.78 \\
\hline 35 & 7.28 & 2,3-butanedione & $\mathrm{C}_{4} \mathrm{H}_{6} \mathrm{O}_{2}$ & 0.07 & - \\
\hline 36 & 7.40 & 2-butanone & $\mathrm{C}_{4} \mathrm{H}_{8} \mathrm{O}$ & 0.15 & 0.15 \\
\hline 37 & 20.52 & 2-heptanone & $\mathrm{C}_{7} \mathrm{H}_{14} \mathrm{O}$ & 0.29 & 0.19 \\
\hline 38 & 25.91 & 6-methyl-5-heptene-2-one & $\mathrm{C}_{8} \mathrm{H}_{14} \mathrm{O}$ & 0.30 & 0.29 \\
\hline 39 & 40.81 & 2-octanone & $\mathrm{C}_{8} \mathrm{H}_{16} \mathrm{O}$ & 0.04 & 0.06 \\
\hline 40 & 49.43 & 2-tridecanone & $\mathrm{C}_{13} \mathrm{H}_{26} \mathrm{O}$ & 0.36 & - \\
\hline 41 & 57.18 & 2-undecanone & $\mathrm{C}_{11} \mathrm{H}_{22} \mathrm{O}$ & 0.09 & 0.70 \\
\hline 42 & 4.78 & Alcohol & $\mathrm{C}_{2} \mathrm{H}_{6} \mathrm{O}$ & 10.24 & - \\
\hline 43 & 6.11 & Heptyl amineol & $\mathrm{C}_{8} \mathrm{H}_{19} \mathrm{ON}$ & - & 2.02 \\
\hline 44 & 10.27 & Butanol & $\mathrm{C}_{4} \mathrm{H}_{10} \mathrm{O}$ & 0.19 & - \\
\hline 45 & 14.88 & 1-pentanol & $\mathrm{C}_{5} \mathrm{H}_{12} \mathrm{O}$ & 0.64 & 0.78 \\
\hline 46 & 20.06 & 1-hexanol & $\mathrm{C}_{6} \mathrm{H}_{14} \mathrm{O}$ & 0.61 & 0.19 \\
\hline 47 & 25.47 & 1-octen-3-ol & $\mathrm{C}_{8} \mathrm{H}_{16} \mathrm{O}$ & 1.87 & 2.60 \\
\hline 48 & 28.24 & 2-ethyl hexanol & $\mathrm{C}_{8} \mathrm{H}_{18} \mathrm{O}$ & 0.27 & - \\
\hline 49 & 30.58 & Octanol & $\mathrm{C}_{8} \mathrm{H}_{18} \mathrm{O}$ & - & 0.52 \\
\hline 50 & 32.27 & Benzyl alcohol & $\mathrm{C}_{7} \mathrm{H}_{8} \mathrm{O}$ & 0.24 & 0.38 \\
\hline 51 & 35.43 & Heptanol & $\mathrm{C}_{7} \mathrm{H}_{16} \mathrm{O}$ & 0.05 & - \\
\hline 52 & 35.82 & Phen ylethyl alcohol & $\mathrm{C}_{8} \mathrm{H}_{10} \mathrm{O}$ & 0.02 & - \\
\hline 53 & 38.47 & Citronella oil & $\mathrm{C}_{10} \mathrm{H}_{20} \mathrm{O}$ & 0.42 & 0.86 \\
\hline 54 & 3.29 & Ethyl L-Alaninate & $\mathrm{C}_{5} \mathrm{H}_{11} \mathrm{O}_{2} \mathrm{~N}$ & 27.50 & 37.28 \\
\hline 55 & 7.12 & Ethyl acetate & $\mathrm{C}_{4} \mathrm{H}_{8} \mathrm{O}_{2}$ & 0.16 & - \\
\hline 56 & 37.50 & Methyl salicylate & $\mathrm{C}_{8} \mathrm{H}_{8} \mathrm{O}_{3}$ & - & 0.17 \\
\hline 57 & 42.39 & Acetic acid vanilla ester & $\mathrm{C}_{12} \mathrm{H}_{22} \mathrm{O}_{2}$ & - & 0.07 \\
\hline 58 & 65.85 & Phthalic acid diisobutyl ester & $\mathrm{C}_{16} \mathrm{H}_{22} \mathrm{O}_{4}$ & 0.14 & 0.35 \\
\hline 59 & 69.12 & Dibutyl-o-phthalate & $\mathrm{C}_{16} \mathrm{H}_{22} \mathrm{O}_{4}$ & 0.09 & 0.24 \\
\hline 60 & 8.22 & Benzene & $\mathrm{C}_{6} \mathrm{H}_{6}$ & 0.12 & 0.12 \\
\hline 61 & 12.36 & Toluene & $\mathrm{C}_{7} \mathrm{H}_{8}$ & - & 1.40 \\
\hline 62 & 17.02 & Ethylbenzene & $\mathrm{C}_{8} \mathrm{H}_{10}$ & 0.18 & 0.23 \\
\hline 63 & 17.41 & O-xylene & $\mathrm{C}_{8} \mathrm{H}_{10}$ & 0.39 & 0.20 \\
\hline 64 & 29.70 & 1-methyl-4-(1-methylethen yl)benzene & $\mathrm{C}_{10} \mathrm{H}_{12}$ & 0.16 & - \\
\hline 65 & 32.52 & Phen ol & $\mathrm{C}_{6} \mathrm{H}_{6} \mathrm{O}$ & 0.04 & - \\
\hline 66 & 13.39 & Pyridine & $\mathrm{C}_{5} \mathrm{H}_{5} \mathrm{~N}$ & - & 3.02 \\
\hline 67 & 23.26 & 2-pentylfuran & $\mathrm{C}_{9} \mathrm{H}_{14} \mathrm{O}$ & 0.39 & 0.35 \\
\hline 68 & 36.77 & Azulene & $\mathrm{C}_{10} \mathrm{H}_{8}$ & 0.12 & - \\
\hline
\end{tabular}

-: not checked out.

The volatile compounds in cooked blue peafowl eggs and hen eggs are listed in Table 7.

47 volatile compounds were found in raw blue peafowl eggs while only 30 in raw hen eggs; 60 volatile compounds were found in cooked blue peafowl eggs while only 41 in cooked eggs.
The cooked blue peafowl eggs contained higher aldehydes and ketones content than raw blue peafowl eggs, such as hexanal, heptaldehyde, nonenal, benzaldehyde, propanone, especially pentanal and 1-octen-3-alcohol were not detected out in raw blue peafowl eggs. On the contrary, the content and kinds of alkanes in cooked blue 
peafowl eggs were lower than raw blue peafowl eggs. Although we are not sure which kinds and amount of volatile substances are related to eggs' odor and taste, much more these compounds in peafowl eggs and different compounds in cooked and raw eggs are believed to be useful to evaluate two kinds of egg' quality. Further studies should be conducted under more controlled conditions to precisely analyze special characteristics of volatile odorous compounds from two kinds of eggs as well as cooked and raw eggs.

Most of the volatile compounds in cooked blue peafowl eggs were aldehydes (18), alcohol (10), ketones (8), alkanes (10), aromatic hydrocarbon (6). Aldehydes content were the highest, reached up to $36.55 \%$, followed by ester accounted for $28.31 \%$ in cooked blue peafowl eggs; however, ester content was the highest, reached up to $38.97 \%$, followed by aldehydes, accounted for $35.28 \%$ in cooked hen eggs.

\section{Conclusion}

Compared with Jingbai eggs, blue peafowl eggs had better qualities including egg-weight, eggshell thickness, egg-shape index, egg yolk index and Haugh unit. Blue peafowl eggs also possessed more advantages in nutrition owing to its higher carbohydrate and protein but lower fat and cholesterol, richer mineral element ( $\mathrm{Zn}, \mathrm{Se}, \mathrm{Mn}$ and P), higher $\mathrm{V}_{\mathrm{C}}$, reasonable proportion of amino acids and much more volatile compounds than those in hen eggs. In a short, most indexes of qualities and nutrient components of blue peafowl eggs were superior to Jingbai hen eggs. It may be a good egg resource for consumers to choose.

\section{Acknowledgments}

The research was supported by the National Spark Program of the State Ministry of Science \&Technology (2008GA860013) and Scientists and Technicians Service Enterprise Project of the State Ministry of Science \&Technology (2009GJG10020). We are very grateful to Feng Yusheng and Wang Yongsong (China General Chamber of Commerce Food Quality Supervision Testing Center) for their technical assistance.

\section{References}

[1] Wang Ke-hua, Dou Tao-cun, Qu Liang, Guo Jun, Hong Jun, "Comparison and analysis for egg quality of seven breeds of layer”, China Poultry, 34 (5). 23-27. 2012.
[2] Song Ai-yi, Pang Huan-ming, Li Jin-yu, Zhu Zheng-lan, Gulinazi, Wang Zi-rong, "Study on quality and nutrition of eggs on Hy-line brown and Jingbai”, Xinjiang Agricultural Sciences, 49 (2). 330335. 2012.

[3] Chen Ying-kun, E Chen-guang, Liu Ming-shi, "Comparison of the egg, dark egg, quail egg”, Feed Industry, 26 (7). 10-12. 2005.

[4] Mahdavi AH, Rahmani HR, Pourreza J, "Effect of probiotic supplements on egg quality and laying hen's performance”, International journal of poultry science, 4 (7). 488-492. 2005.

[5] Panda AK, Rama-rao SS, Raju MV. Effect of probiotic (Lactobacillus sporogenes) feeding on egg production and quality, yolk cholesterol and humoral immune response of White Leghorn layer breeders. Journal of the science of food and agriculture, 2007; 88: 43-47.

[6] Gallazzi D., Giardini A., Mangiagalli MG., "Effects of Lactobacillus acidophilus D2/CSL on laying hen performance", The Italian journal of animal science, 7 (1). 27-37. 2008.

[7] Zhang $\mathrm{Xu}$, Zou Wang-ping, Hu Yan, Jiang Gui-tao, Wang Xiangrong, Li Hao-bang, Dai Qiu-zhong, "Effects of bacillus on performance and egg quality of layers”, Acta ecologiae animalis domastici, 31 (6). 34-38.2010.

[8] Wei Qi-peng, Zeng Tao, Li Guo-qin, “Comparison of hemp duck egg quality and ingredients under different feeding mode", China animal husbandry \& veterinary medicine, 39 (2). 228-230. 2012.

[9] Luan Xin-hong, Su Dan, Liu Mei, Gao Ming, Wang Lai-you, Zhang Shi-wei, "Effects of daidzein on the egg laying performance and egg quality of Huoyan geese at the earlier stage of laying period”, China feed, 9. 27-35. 2013.

[10] Ma Mei-hu, "Egg and egg products processing”, China agriculture press, 2007.

[11] Xu Gui-yun, Hou Zhuo-cheng, Nin Zhong-hua, Yang Ning, Yang Chang-suo, "Analysis and comparison of different laying hens eggs”, Guide to Chinese poultry, 20 (12). 32-33. 2003.

[12] Wang Shi-cheng, Fu Chuan-mo, Sun Guo-qiang, "Effect of egg shape index, weight and specific gravity on hatchability and sex ratio”, Journal of Laiyang agricultural college, 14 (3). 206-209. 1997.

[13] Peng Xiu-li, Den Gan-zhen, Ruan Guo-qing, “Affection of egg shape index on hatchability sex ratio", Sichuan animal and veterinary science, 29 (2). 23-24. 2002.

[14] Zhang Yi-yu, Zhang Fu-ping, Wu Chao-ling, Yang Hong-mao, Lin Jia-dong, Cen Juan-hua, Pan Lan-bing, "Analysis of egg quality and nutritional components of Sizhou hen”, Journal of southern agriculture, 44 (4). 671-675. 2013.

[15] Ge Qing-lian, Zhang Shuang-jie, "Influencing factors and comparison and improvement of the evaluation method on the shell quality”, China poultry, 25 (2). 37-38. 2003.

[16] Li Zeng-bao, "Physical and chemical inspection of animal food", China Agriculture Press, 1990.

[17] Zhou You-xiang, Xia Hong, Peng Mao-min, Wang Qing-qing, Hu Ding-jin, "Preliminary nutritional analysis of fresh duck egg and its products", Hubei agricultural sciences, 48 (10). 2553-2556. 2009.

[18] Liu Tai-yu, Shi Su-rong, "Quality comparison of ostrich egg”, Chinese Journal of Animal Science, 34 (2). 56-57. 1998. 